\title{
Sistem Pendukung Keputusan untuk Penentuan Minat Peserta Didik di SMA Menggunakan Metode TOPSIS
}

\author{
Afrian Suryandini dan Indriyati \\ Jurusan IlmuKomputer/Informatika, FakultasSainsdan Matematika, UniversitasDiponegoro \\ afrian.suryandini@gmail.com
}

\begin{abstract}
Abstrak
Penyelenggaraan pendidikan dalam satuan pendidikan di SMA berdasarkan kurikulum 2013 terdapat program penentuan minat peserta didik yang dilaksanakan di kelas X. Pilihan minat yang tersedia meliputi bidang minat Matematika dan Ilmu Alam serta Ilmu Ilmu Sosial. Penentuan minat dilakukan oleh guru BP / BK melalui proses penyeleksian dengan melihat kriteria-kriteria seperti prioritas minat, nilai ujian nasional, hasil psikotes, dan nilai placement test. Proses penentuan minat secara manual seringkali menemukan banyak masalah seperti banyaknya kriteria yang digunakan dan banyaknya jumlah pendaftar. Oleh karena itu, dibutuhkan sebuah Sistem Pendukung Keputusan yang dapat mengatasi permasalahan tersebut. Pada penelitian ini, sistem ini menggunakan metode TOPSIS karena hasil perhitungan TOPSIS minat Matematika dan Ilmu Alam akan dibandingkan dengan hasil perhitungan TOPSIS minat Ilmu Ilmu Sosial sehingga didapatkan hasil penentuan minat sesuai dengan nilai tertinggi dari perbandingan kedua hasil perhitungan TOPSIS tersebut. Data penentuan minat tahun 2014 di SMA Negeri 1 Bekasi digunakan sebagai masukan dengan hasil penentuan minat sistem sebagai keluaran. Hasil penentuan sistem menghasilkan akurasi sebesar $96.65 \%$ yang didapatkan dari membandingkan hasil penentuan minat sistem dengan data penentuan minat tahun 2014 di SMA Negeri 1 Bekasi.
\end{abstract}

Kata Kunci : Sistem Pendukung Keputusan, Penentuan Minat, TOPSIS

\section{Pendahuluan}

Penyelenggaraan pendidikan dalam satuan pendidikan di SMA/MA pada kurikulum 2013 terdapat program penentuan minat/ peminatan peserta didik yang dilaksanakan di kelas $\mathrm{X}$. Peminatan peserta didik dapat diartikan suatu proses yang berkesinambungan untuk memfasilitasi peserta didik mencapai keberhasilan proses dan hasil belajar serta perkembangan optimal dalam rangka mencapai tujuan pendidikan nasional [4].

Proses penentuan minat peserta didik oleh guru BK seringkali menghabiskan waktu yang lama karena terbatasnya jumlah guru BK dan banyaknya jumlah peserta didik baru yang ada di sekolah tersebut. Penentuan minat pun terkadang bersifat subjektif dan melibatkan banyak kriteria karena sulitnya guru BK untuk menentukan peminatan peserta didik. Kriteria yang digunakan dalam pengambilan keputusan ditentukanberdasarkan kurikulum 2013 dan kebijakan sekolah. Salah satu metode yang dapat digunakan untuk pengambilan keputusan adalah metode teknik kedekatan nilai preferensi terhadap solusi ideal atau yang lebih dikenal dengan
Technique for Order Prefence by Similarity to Ideal Solution (TOPSIS). Metode TOPSIS merupakan metode pendukung keputusan yang didasarkan pada konsep bahwa alternatif yang terbaik tidak hanya memiliki jarak terpendek dari solusi ideal positif tetapi juga memiliki jarak terpanjang dari solusi ideal negatif [6].Berdasarkan hal tersebut maka TOPSIS dapat digunakan karena hasil perhitungan TOPSIS minat MIA akan dibandingkan dengan hasil perhitungan TOPSIS minat IIS sehingga didapatkan hasil penentuan minat sesuai dengan nilai tertinggi dari perbandingan kedua hasil perhitungan TOPSIS tersebut.

Metode TOPSIS telah banyak diimplementasikan sebagai metode untuk membangun system pendukung keputusan. Beberapa penelitian sudah menggunakan metode TOPSIS untuk pengambilan keputusan. Salah satunya adalah penelitian dari Xiaoqian Zhu, Fei Wang, Haiyan Wang, Changzhi Liang, Run Tang, Xiaolei Sun, Jianping Li mengenai "TOPSIS method for quality credit evaluation: A case of air conditioning market inChina". Penelitian tersebut menghasilkan beberapa kesimpulan, yaitu dengan menggunakan sistem 
indikator dan metode TOPSIS, setiap perusahaan dapat mencapai nilai kredit yang berkualitas yangmemberikan pandangan yang jelas dari kondisi kualitas kredit dari perusahaan.Semakin besar nilai kredit, semakin baik kualitas kredit dari perusahaan diharapkan, dan sebaliknya. Rata kualitas kreditdapat digunakan sebagai referensi penting bagi konsumen, perusahaandan pemerintah dalam pengambilan keputusan [6].

\section{TinjauanPustaka}

\subsection{Peminatan Peserta Didik}

Peminatan adalah proses yang berkesinambungan, peminatan harus berpijak pada kaidah-kaidah dasar yang secara eksplisit dan implisit, terkandung dalam kurikulum. Peminatan pilihan kelompok mata pelajaran, pilihan lintas mata pelajaran dan pilihan pendalaman materi mata pelajaran merupakan upaya untuk membantu peserta didik dalam memilih dan menetapkan mata pelajaran yang diikuti pada satuan pendidikan di SMA, memahami dan memilih arah pengembangan karir, dan menyiapkan diri serta memilih pendidikan lanjutan sampai ke perguruan tinggi sesuai dengan kemampuan dasar umum, bakat, minat dan kecenderungan pilihan masing-masing peserta didik [4].

\subsection{Sistem Pendukung Keputusan}

Sistem Pendukung Keputusan (SPK) adalah sistem berbasis komputer yang terdiri dari tiga komponen yang saling berinteraksi, yaitu sistem bahasa, sistem pengetahuan, dan sistem pemrosesan masalah. SPK juga sebagai sistem yang dapat diperluas untuk mampu mendukung analisis data ad hoc dan pemodelan keputusan, berorientasi terhadap perencanaan masa depan, dan digunakan pada interval yang tidak reguler dan tak terencana [2].

\subsection{Komponen Sistem Pendukung Keputusan}

Terdapat berbagai komponen dalam Sistem Pendukung Keputusan seperti terlihat dalam Gambar 1 [3].

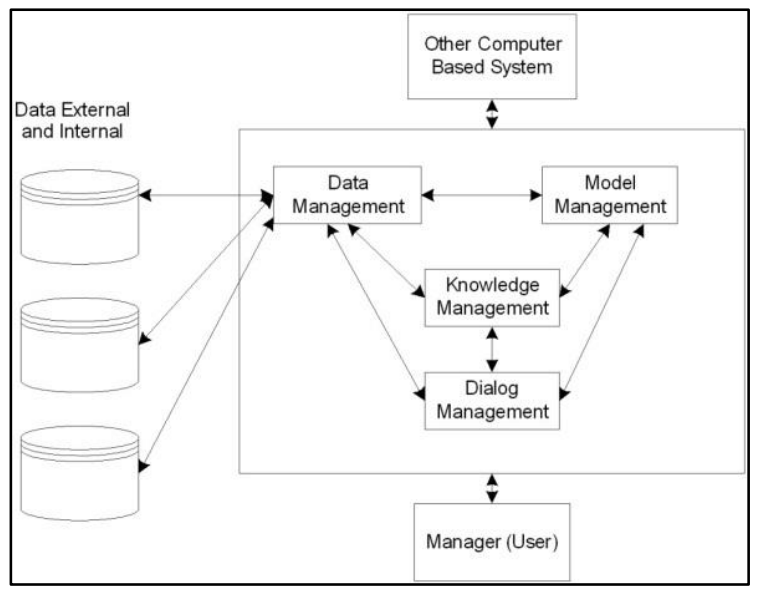

Gambar 1. Komponen Sistem Pendukung Keputusan.

1. Data Management, mencakup database yang relevan yang diatur oleh software yang disebut Database Management System (DBMS).

2. Model Management, merupakan paket perangkat lunak yang memasukkan modelmodel finansial, statistik, ilmu manajemen, atau model kuantitatif yang lain yang menyediakan kemampuan analisis sistem dan management software yang terkait.

3. Communication, atau biasa disebut antarmuka pengguna merupakan sebuah komponen yang bertindak sebagai media interaksi antara sistem dengan pengguna.

4. Knowledge Management, komponen ini bersifat optional. Komponen ini dapat mendukung komponen lain atau bertindak sebagai komponen yang berdiri sendiri.

\subsection{Pengambilan Keputusan Multi Atribut}

Sebagian besar pendekatan pengambilan keputusan multi atribut dilakukan melalui 2 langkah, yaitu: melakukan agregasi terhadap keputusan-keputusan yang tanggap terhadap semua tujuan pada setiap alternatif dan melakukan perankingan alternatif-alternatif keputusan tersebut berdasarkan hasil agregasi keputusan.

$X=\left[\begin{array}{cccc}\mathrm{x}_{11} & \mathrm{x}_{12} & \ldots & \mathrm{x}_{1 \mathrm{n}} \\ \mathrm{x}_{21} & \mathrm{x}_{22} & \cdots & \mathrm{x}_{2 \mathrm{n}} \\ \vdots & \vdots & & \vdots \\ \mathrm{x}_{\mathrm{m} 1} & \mathrm{x}_{\mathrm{m} 2} & \cdots & \mathrm{x}_{\mathrm{mn}}\end{array}\right]$ 
$\mathrm{X}_{\mathrm{ij}} \mathrm{yang}$ ada dalam persamaan 2.1 merupakan rating kinerja alternatifke-i terhadapatributke-j.

$\mathrm{W}=\left\{\mathrm{w}_{1}, \mathrm{w}_{2}, \ldots, \mathrm{w}_{\mathrm{n}}\right\}$

W yang ada dalam persamaan 2 merupakan nilaibobot yang menunjukkan tingkat kepentingan relative setiap atribut. [5].

\subsection{Technique for Order Prefence by Similarity to Ideal Solution (TOPSIS)}

Secara umum, prosedur TOPSIS mengikuti langkah-langkah sebagai berikut [1] :

1. Membuat matriks keputusan yang ternormalisasi (R).

Normalisasi nilai atribut untuk membentuk matriks ternormalisasi $(\mathrm{R})$ dengan persamaan 3.

$r_{i j}=\frac{x_{i j}}{\sqrt{\sum_{j=1}^{m} x_{i j}^{2}}},(i=1,2, \ldots, n ; j=1,2, \ldots, m)$

$\mathrm{x}_{\mathrm{ij}}$ merupakan rating kinerja alternative ke-i terhadap atributke-j dan $\mathrm{r}_{\mathrm{ij}}$ adalah elemen dari matriks keputusan yang ternormalisasi.

2. Membuat matriks keputusan yang ternormalisasi terbobot $(\mathrm{Y})$.

Perkalian antara bobot dengan nilai setiap atribut dihitung dengan persamaan 4 .

$\mathrm{Y}=\left[\begin{array}{llll}\mathrm{y}_{11} & \mathrm{y}_{12} & \ldots & \mathrm{y}_{1 \mathrm{j}} \\ \mathrm{y}_{21} & \mathrm{y}_{22} & \ldots & \mathrm{y}_{2 \mathrm{j}} \\ \vdots & \vdots & \ddots & \vdots \\ \mathrm{y}_{\mathrm{i} 1} & \mathrm{y}_{\mathrm{i} 2} & \cdots & \mathrm{y}_{\mathrm{ij}}\end{array}\right]$ untuk $\mathrm{y}_{\mathrm{ij}}=\mathrm{w}_{\mathrm{j}} \mathrm{r}_{\mathrm{ij}}$

$\mathrm{w}_{\mathrm{j}}$ adalah bobot dari kriteria ke-j dan $\mathrm{y}_{\mathrm{ij}}$ adalah elemen dari matriks keputusan yang ternormalisasi terbobot.

3. Menentukan matriks solusi ideal positif $\left(\mathrm{A}^{+}\right)$ dan matriks solusi ideal negatif $\left(\mathrm{A}^{-}\right)$

$\mathrm{A}^{+}=\left(\mathrm{y}_{1}^{+}, \mathrm{y}_{2}^{+}, \ldots, \mathrm{y}_{\mathrm{j}}^{+}\right)$
$\mathrm{A}^{-}=\left(\mathrm{y}_{1}^{-}, \mathrm{y}_{2}^{-}, \ldots, \mathrm{y}_{\mathrm{j}}^{-}\right)$

Dengan

$y_{j}^{+}=\left\{\begin{array}{c}\max _{i} y_{i j}, j i k a j=\text { keuntungan } \\ \min _{i} y_{i j}, j i k a j=\text { biaya }\end{array}\right.$ $y_{j}^{-}=\left\{\begin{array}{l}\min _{i} y_{i j}, j i k a j=\text { keuntungan } \\ \max _{i} y_{i j}, j i k a j=\text { biaya }\end{array}\right.$

4. Menentukan jarak antara nilai setiap alternative dengan matriks solusi ideal positif dan matriks solusi ideal negatif.

Jarak solusi ideal positif $\left(\mathrm{d}_{\mathrm{i}}^{+}\right)$dirumuskan sebagai:

$\mathrm{d}_{\mathrm{i}}^{+}=\sqrt{\sum_{\mathrm{j}=1}^{\mathrm{m}}\left(\mathrm{y}_{\mathrm{ij}}-\mathrm{y}_{\mathrm{j}}^{+}\right)^{2}}$

$y_{j}^{+}$adalah elemen dari matriks solusi ideal positif. Jaraksolusi ideal negatif $\left(\mathrm{d}_{\mathrm{i}}^{-}\right)$ dirumuskan sebagai:

$d_{i}^{-}=\sqrt{\sum_{j=1}^{m}\left(y_{i j}-y_{j}^{-}\right)^{2}}$

$y_{j}^{-}$adalah elemen dari matriks solusi ideal negatif.

5. Menentukan nilai preferensi $\left(\mathrm{c}_{\mathrm{i}}\right)$ untuk setiap alternatif. Nilai preferensi merupakan kedekatan suatu alternative terhadap solusi ideal.

$\mathrm{c}_{\mathrm{i}}=\frac{\mathrm{d}_{\mathrm{i}}^{-}}{\mathrm{d}_{\mathrm{i}}^{-}+\mathrm{d}_{\mathrm{i}}^{+}}$

$\mathrm{d}_{\mathrm{i}}^{+}$adalah jarak solusi ideal positif dan $\mathrm{d}_{\mathrm{i}}^{-}$ adalah jarak solusi ideal negatif. Nilai $c_{i}$ yang lebih besar menunjukkan bahwa alternative tersebut lebih dipilih.

\section{Implementasi dan Pembahasan}

\subsection{Analisis Penentuan Minat Peserta Didik}

Kriteria yang digunakan dalam proses penyeleksian minat adalah prioritas minat, nilai UN, psikotest, dan nilai Placement Test (PT). Adapun rating kriteria yang diberikan kepada tiap kriteria berbeda-beda seperti dijelaskan pada Tabel 1 dan nilai alternatif dari setiap kriteria untuk masing-masing minat pada Tabel 2 . 
Tabel 1. Nilai Linguistik Untuk Kriteria

\begin{tabular}{ll}
\hline \multicolumn{1}{c}{ Kriteria } & \multicolumn{1}{c}{ Rating } \\
\hline Prioritas Minat & Sangat Tinggi \\
Nilai UN & $\begin{array}{l}\text { Tengah- } \\
\text { Tengah }\end{array}$ \\
Psikotest & Tinggi \\
Nilai Placement Test & Sangat Tinggi \\
\hline
\end{tabular}

Tabel 2. Konversi Alternatif Berdasarkan Nilai Linguistik

\begin{tabular}{rrrrlr}
\hline Prioritas Minat & Nilai Placement Test & Nilai UN & Psikotest & \multicolumn{1}{c}{ Rating } & Bobot \\
\hline 1 & $81-100$ & $9.51-10.00$ & 1 & Sangat Tinggi & 5 \\
2 & $71-80$ & $9.01-9.50$ & & Tinggi & 4 \\
& $61-70$ & $8.51-9.00$ & 2 & Tengah-Tengah & 3 \\
& $41-60$ & $8.01-8.50$ & & Rendah & 2 \\
& $0-40$ & $0-8.00$ & & Sangat Rendah & 1 \\
\hline
\end{tabular}

\subsection{Analisis Perhitungan}

Tabel 3. Data Alternatif Minat MIA

\begin{tabular}{cccrr}
\hline $\begin{array}{c}\text { Id } \\
\text { Alter- } \\
\text { natif }\end{array}$ & $\begin{array}{c}\text { Prioritas } \\
\text { Minat }\end{array}$ & \multicolumn{1}{c}{$\begin{array}{c}\text { Nilai } \\
\text { UN }\end{array}$} & \multicolumn{1}{c}{$\begin{array}{c}\text { Psiko } \\
\text { test }\end{array}$} & \multicolumn{1}{c}{$\begin{array}{c}\text { Nilai } \\
\text { PT }\end{array}$} \\
\hline 140001 & 1 & 9,01 & 1 & 59 \\
140002 & 1 & 9,53 & 1 & 82,5 \\
140003 & 1 & 9,01 & 2 & 28 \\
140004 & 2 & 9,46 & 2 & 72 \\
140005 & 2 & 8,93 & 1 & 54 \\
140006 & 1 & 9,01 & 1 & 81 \\
140007 & 1 & 8,96 & 1 & 79 \\
\hline
\end{tabular}

Langkah penyelesaian masalah terhadap

Tabel 3 dengan metode TOPSIS adalah :

1. Membuat matriks keputusan (X) dengan cara mengkonversi data awal menjadi data yang sesuai dengan rating alternatif pada Tabel 2. Matriks bobot (W) adalah nilai bobot dari masing - masing kriteria pada Tabel 3.

$$
X=\left[\begin{array}{llll}
5 & 4 & 5 & 2 \\
5 & 5 & 5 & 5 \\
5 & 4 & 3 & 1 \\
3 & 4 & 3 & 4 \\
3 & 3 & 5 & 2 \\
5 & 4 & 5 & 5 \\
5 & 3 & 5 & 4
\end{array}\right] \quad W=\left[\begin{array}{l}
5 \\
3 \\
4 \\
5
\end{array}\right]
$$

2. Membuat matriks keputusan ternormalisasi berdasarkan persamaan 3 .

$$
R=\left[\begin{array}{llll}
0,4181 & 0,3867 & 0,4181 & 0,2097 \\
0,4181 & 0,4834 & 0,4181 & 0,5241 \\
0,4181 & 0,3867 & 0,2509 & 0,1048 \\
0,2509 & 0,3867 & 0,2509 & 0,4193 \\
0,2509 & 0,2900 & 0,4181 & 0,2097 \\
0,4181 & 0,3867 & 0,4181 & 0,5241 \\
0,4181 & 0,2900 & 0,4181 & 0,4193
\end{array}\right]
$$

3. Membuat matriks keputusan ternormalisasi terbobot berdasarkan persamaan 4 .

$$
Y=\left[\begin{array}{llll}
2,0906 & 1,1601 & 1,6725 & 1,0483 \\
2,0906 & 1,4501 & 1,6725 & 2,6207 \\
2,0906 & 1,1601 & 1,0035 & 0,5241 \\
1,2544 & 1,1601 & 1,0035 & 2,0966 \\
1,2544 & 0,8701 & 1,6725 & 1,0483 \\
2,0906 & 1,1601 & 1,6725 & 2,6207 \\
2,0906 & 0,8701 & 1,6725 & 2,0966
\end{array}\right]
$$

4. Menentukan solusi ideal positif $\left(\mathrm{A}^{+}\right)$dan solusi ideal negatif $\left(\mathrm{A}^{-}\right)$berdasarkan persamaan 5, 6, 7, dan 8 .

$\mathrm{A}^{+}=\{2,0906 ; 1,4501 ; 1,6725 ; 2,6207\}$

$A^{-}=\{1,2544 ; 0,8701 ; 1,0035 ; 0,5241\}$

5. Menentukan jarak solusi ideal positif $\left(\mathrm{d}^{+}\right)$ dan jarak solusi ideal negatif berdasarkan persamaan 9 dan 10 . 


$$
\mathrm{d}^{+}=\left[\begin{array}{c}
1,5989 \\
0 \\
2,2197 \\
1,2271 \\
1,8730 \\
0,2900 \\
0,7818
\end{array}\right] \quad \mathrm{d}^{-}=\left[\begin{array}{c}
1,2271 \\
2,4246 \\
0,8851 \\
1,5989 \\
0,8499 \\
2,3720 \\
1,9025
\end{array}\right]
$$

6. Menentukan kedekatan nilai preferensi tiap alternatif (ci) berdasarkan persamaan 11 .

$$
\begin{aligned}
& c 1=\frac{1,2271}{(1,5989+1,2271)}=0,4342 \\
& \text { c2 }=\frac{2,4246}{(0+2,4246)}=1 \\
& \text { c3 }=\frac{0,8851}{(2,2197+0,8851)}=0,2851 \\
& \text { c4 }=\frac{1,5989}{(1,2271+1,5989)}=0,5658 \\
& \text { c5 }=\frac{0,8499}{(1,8730+0,8499)}=0,3121 \\
& \text { c6 }=\frac{2,3720}{(0,2900+2,3720)}=0,8911 \\
& \text { c7 }=\frac{1,9025}{(0,7818+1,9025)}=0,7088
\end{aligned}
$$

Tabel 4. Data Alternatif Minat IIS

\begin{tabular}{crrrr}
\hline $\begin{array}{c}\text { Id } \\
\text { Alter- } \\
\text { natif }\end{array}$ & $\begin{array}{c}\text { Prioritas } \\
\text { Minat }\end{array}$ & $\begin{array}{c}\text { Nilai } \\
\text { UN }\end{array}$ & $\begin{array}{c}\text { Psiko } \\
\text { test }\end{array}$ & $\begin{array}{c}\text { Nilai } \\
\text { PT }\end{array}$ \\
\hline 140001 & 2 & 9,4 & 2 & 44 \\
140002 & 2 & 9,61 & 2 & 85 \\
140003 & 2 & 9,2 & 1 & 39 \\
140004 & 1 & 9,5 & 1 & 79 \\
140005 & 1 & 9 & 2 & 59 \\
140006 & 2 & 9,2 & 2 & 82 \\
140007 & 2 & 8,54 & 2 & 72 \\
\hline
\end{tabular}

Langkah penyelesaian masalah terhadap Tabel 3.4 dengan metode TOPSIS sama dengan yang dilakukan terhadap Tabel 3.3 sehingga didapatkan nilai preferensi tiap alternatif Minat IIS, yaitu :

$$
\begin{aligned}
& c 1=\frac{0,5990}{(2,0695+0,5990)}=0,2245 \\
& c 2=\frac{2,1753}{(1,3139+2,1753)}=0,6234
\end{aligned}
$$

$$
\begin{aligned}
& \text { c3 }=\frac{0,8705}{(2,3521+0,8705)}=0,2701 \\
& \text { c4 }=\frac{2,0695}{(0,5990+2,0695)}=0,7755 \\
& \text { c5 }=\frac{1,1521}{(1,8662+1,1521)}=0,3817 \\
& \text { c6 }=\frac{2,1165}{(1,3455+2,1165)}=0,6114 \\
& \text { c7 }=\frac{1,5724}{(1,5289+1,5724)}=0,5070
\end{aligned}
$$

Penentuan minat didasarkan dari perbandingan nilai hasil perhitungan TOPSIS minat MIA dan minat IIS. Jika siswa memiliki nilai minat MIA lebih besar dari nilai minat IIS, maka siswa tersebut direkomendasikan menjadi siswa minat MIA. Jika siswa memiliki nilai minat IIS lebih besar dari nilai minat MIA, maka siswa tersebut direkomendasikan menjadi siswa minat IIS. Hasil penentuan minat adalah sebagai berikut :
1. 140001 : minat MIA
2. 140002 : minat MIA
3. 140003 : minat MIA
4. 140004 : minat IIS
5. $140005:$ minat IIS
6. 140006 : minat MIA
7. 140007 : minat MIA

\subsection{Antarmuka}

Antarmuka pada SPK Penentuan Minat Peserta Didik di SMA Menggunakan Metode TOPSIS terbagi menjadi empat bagian yaitu antarmuka awal sistem, antarmuka pengguna Administrator, antarmuka pengguna Guru BK, dan antarmuka pengguna Pendaftar

1. Antarmuka Awal Sistem

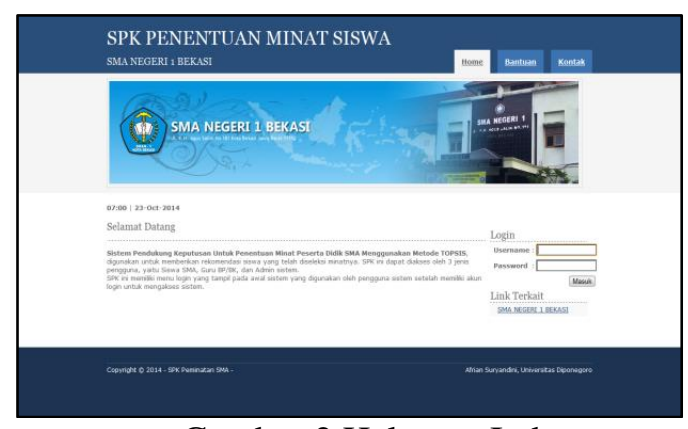

Gambar 2.Halaman Index 
Gambar 2 menampilkan halaman index. Halaman ini adalah tampilan awal dari sistem.

2. Antarmuka Pengguna Administrator

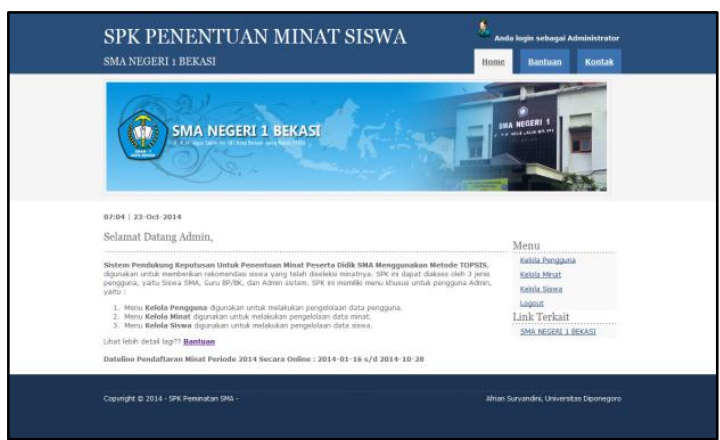

Gambar 3 Menu Utama Administrator

Gambar 3 menampilkanhalaman menu utama administrator. Halaman ini adalah tampilan awal dari pengguna Administrator.

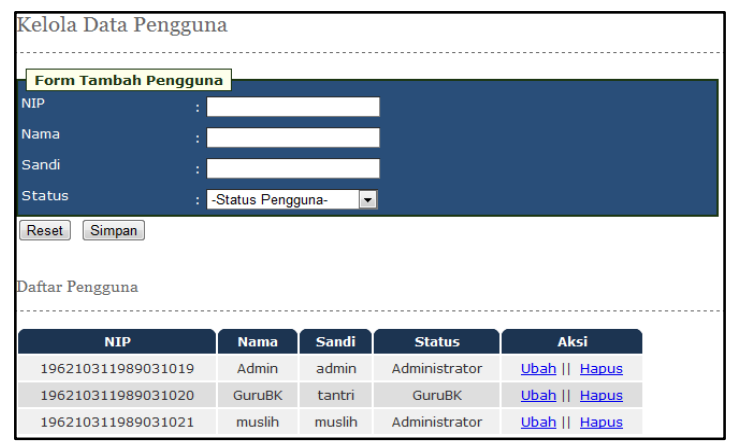

Gambar 4 Halaman Kelola Pengguna

Gambar 4 menampilkan halaman kelola pengguna. Halaman ini memiliki fitur untuk menambah, mengubah dan menghapus data pengguna.

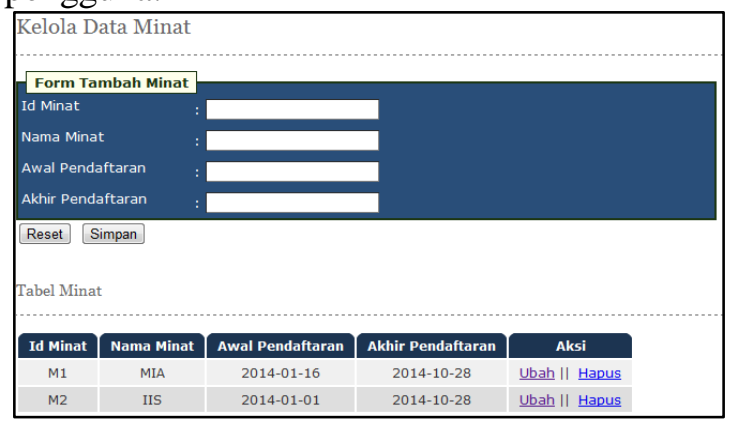

Gambar 5 Halaman Kelola Minat

Gambar 5 menampilkan halaman kelola minat. Halaman ini memiliki fitur untuk menambah, mengubah dan menghapus data minat.

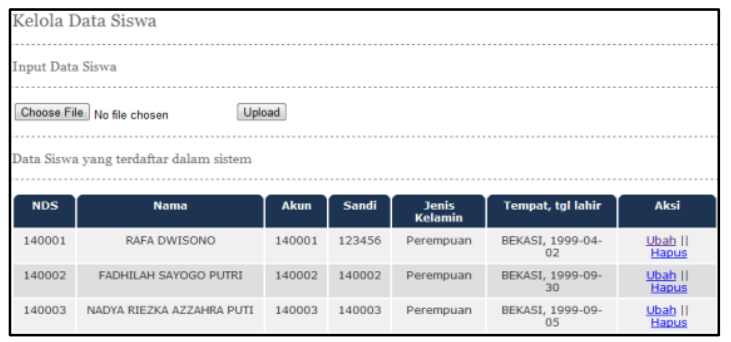

Gambar 6 Halaman Kelola Siswa

Gambar 6 menampilkan halaman kelola siswa. Halaman ini memiliki fitur untuk menambah, mengubah dan menghapus data siswa.

\section{Antarmuka Pengguna Guru BK}

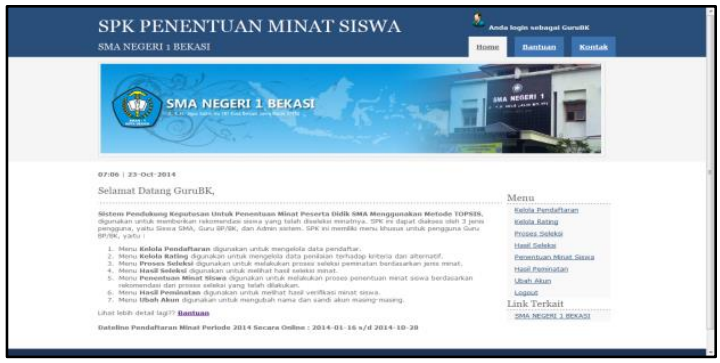

Gambar 7 Menu Utama Guru BK

Gambar 7 menampilkan halaman menu utama administrator. Halaman ini adalah tampilan awal dari pengguna Guru BK.

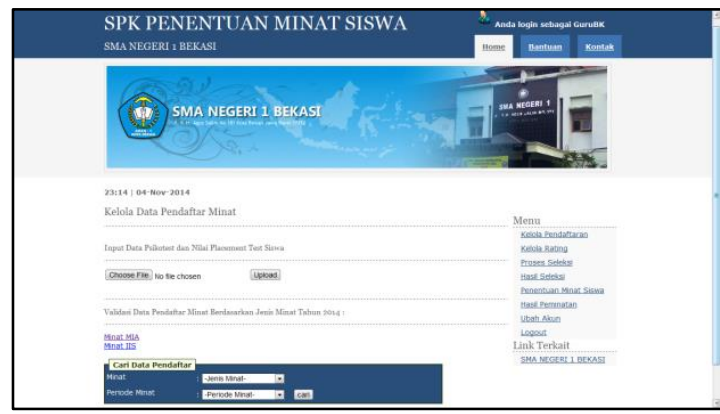

Gambar 8 KelolaData Pendaftar

Gambar 8 menampilkan halaman kelola data pendaftar minat.Halaman ini memiliki fitur untuk input nilai placement test dan hasil psikotes, memvalidasidanmenghapus data pendaftar. 


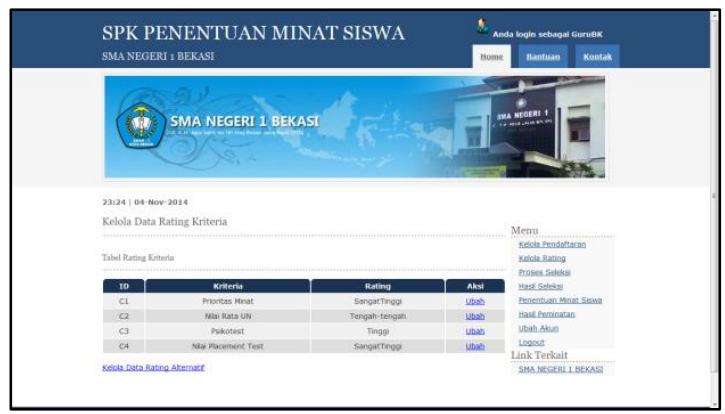

Gambar 9. Kelola Rating

Gambar 9. Menampilkan halaman kelola rating. Halaman ini memiliki fitur untuk mengubah rating kriteria serta menambah, mengubah, dan menghapus rating alternatif.

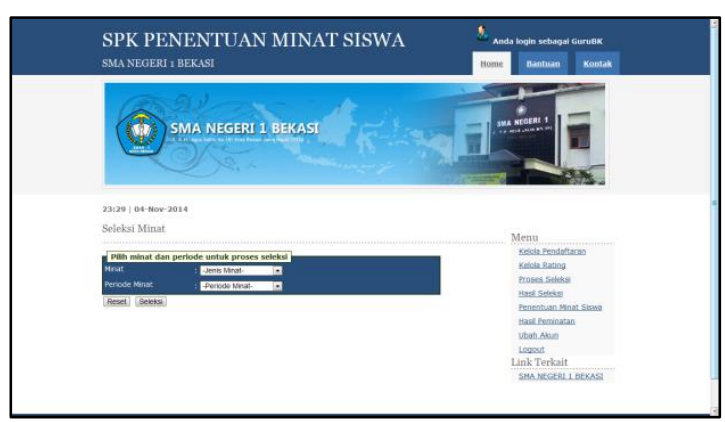

Gambar 10 Proses Seleksi

Gambar 10 menampilkan halaman proses seleksi. Pada halaman ini user memilih jenis dan periode minat yang ingin diproses.

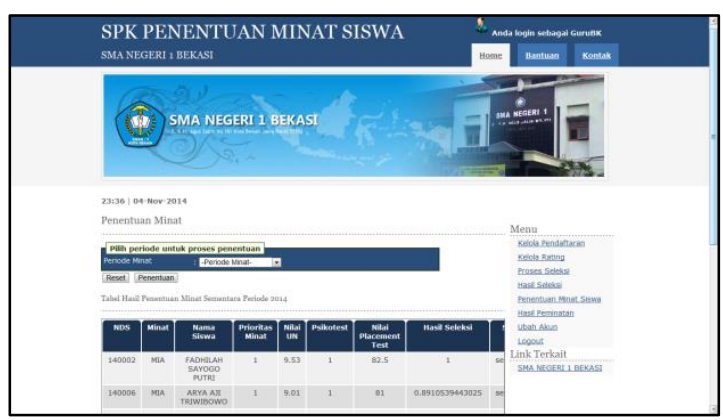

Gambar 11 Penentuan Minat Siswa

Gambar 11 menampilkan halaman penentuan minat siswa. Pada halaman ini terdapat tabel hasil proses perhitungan TOPSIS.Penentuan dapat dilakukan dengan memilih periode minat.

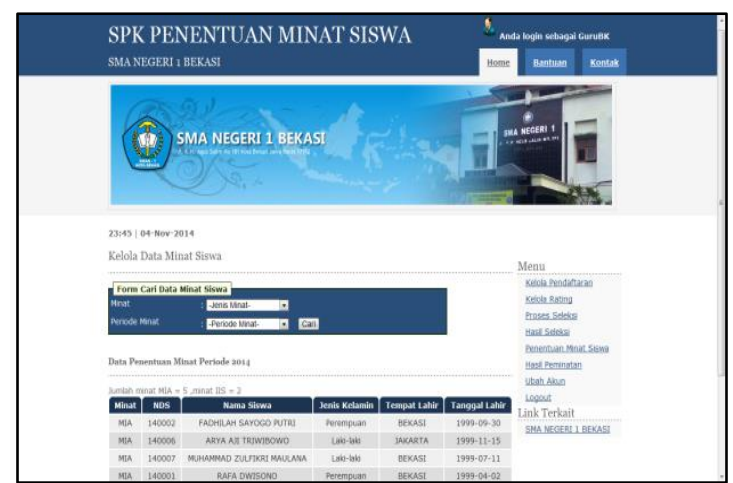

Gambar 12 Hasil Peminatan

Gambar 12 menampilkan halamanhasil peminatan. Pada halaman ini terdapat tabel hasil penentuan minat.Hasil penentuan minat dapat didownload dengan menekan tombol Download Excel setelah tabel data minat siswa. Hasil download dapat dilihat pada Gambar 13.

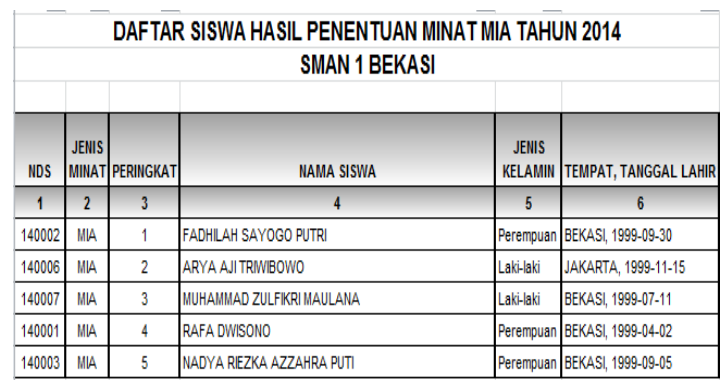

Gambar 13 Hasil Download Penentuan Minat

\section{Antarmuka Pengguna Pendaftar}

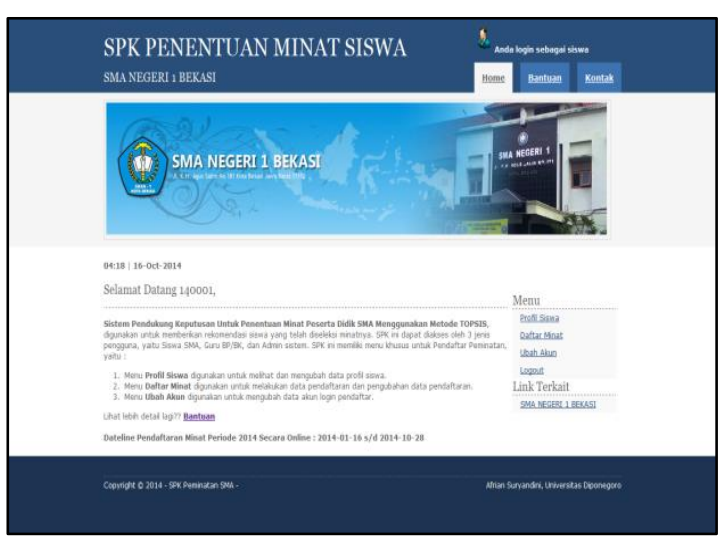

Gambar 14 Menu Utama Pendaftar

Gambar 14 menampilkan halaman menu utama administrator. Halaman ini adalah tampilan awal dari pengguna Pendaftar. 


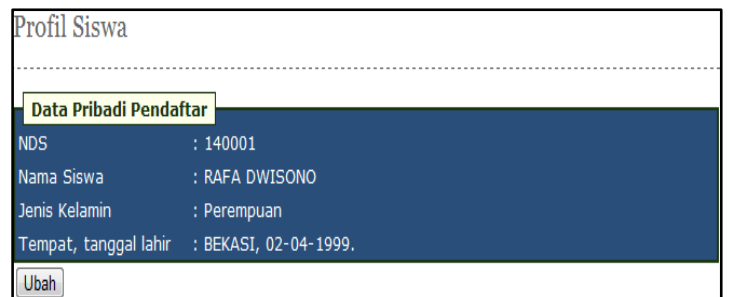

Gambar 15 Halaman Profil Siswa

Gambar 15 menampilkan halaman profil siswa. Halaman ini memiliki fitur untuk mengubah data profil siswa.

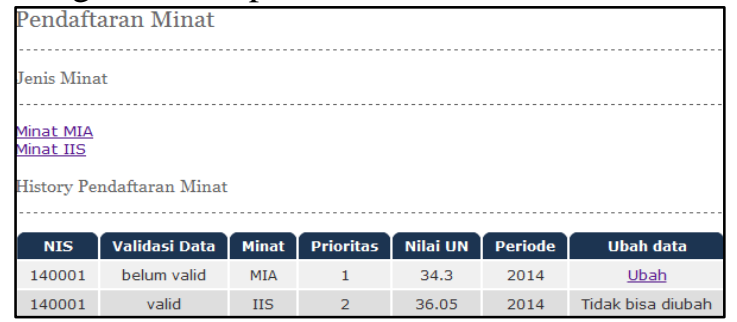

Gambar 16 Halaman Daftar Minat

Gambar 16 menampilkan halaman daftar minat. Halaman ini memiliki fitur untuk menambah dan mengubah data pendaftaran.

\section{Kesimpulan}

Sistem Pendukung Keputusan Penentuan Minat Peserta Didik di SMAMenggunakan Metode TOPSIS yang telah dibuat berdasarkan kriteria yang telah ditentukan menghasilkan data hasil penentuan minat dengan tingkat akurasi $96.65 \%$.Saran yang dapat dilaksanakan untuk pengembangan Sistem Pendukung Keputusan Untuk Penentuan Minat Peserta Didik lebih lanjut adalah Penggunaan metode sistem Pendukung keputusan lainnya dapat dilakukan untuk melihat kemampuan serta kelebihan dari masing-masing metode.

\section{Ucapan Terima Kasih}

Penulis mengucapkan terima kasih kepada SMA Negeri 1 Bekasi selaku tempat penelitian yang telah memberikan data mengenai penentuan minat sehingga penelitian ini dapat diselesaikan dengan baik.

\section{Daftar Pustaka}

[1] D.L.Olson. 2000, "Comparison of weights in TOPSIS models'. Journal of Mathematical and computer modelling. pp.721-727.

[2] E.Turban, J.E. Aronson, danT.P.Liang. 2005,"Decision Support Systems and Intelligent Systems". In D. Prabantini,"Sistem Pendukung Keputusan dan Sistem Cerdas. Edisi 7 Jilid 1" (pp. 137-145). Yogyakarta: Andi.

[3] I.Subakti. 2002, "Sistem Pendukung Keputusan".Surabaya: Institut Teknologi Sepuluh November.

[4] Kemendikbud. 2013, "Pedoman Peminatan Peserta Didik". Jakarta.

[5] S. Kusumadewi, S.Hartati, A.Harjoko, dan R. Wardoyo.2006, "Fuzzy Multy Attribute Decision Making (FUZZY MADM)".Yogyakarta: Graha Ilmu.

[6] Xiaoqian Zhu, Fei Wang, Haiyan Wang, Changzhi Liang, Run Tang, Xiaolei Sun, Jianping Li,"TOPSIS method for quality credit evaluation: A case of air-conditioning market in China".Elsevier. Journal of Computational Science. 5:99-105. 